\title{
Benchmarks
}

\section{Quality Control of Centrifugal Elutriation for Studies of Cell Cycle Regulations}

BioTechniques 23:232-237 (August 1997)

An essential and probably primary task in the study of cell cycle regulations is the synchronization of cells into specific cell cycle phases. Most of the information on cell cycle-related processes has been gained in the past through the use of chemicals or growth restriction conditions to synchronize cells (10). Logarithmically growing cells can alternatively be separated by centrifugal elutriation, which does not require an arrest of the cell cycle to obtain synchronized cells. By this method, cells are separated on the basis of size and, to a lesser extent, density under moderate conditions, making it ideal for isolating populations of cells in specific phases of the cell cycle with minimal metabolic perturbations (7). Centrifugal elutriation has already been used in several different studies of cell cycle-dependent parameters, such as the regulation of cyclins and their associated kinases or E2F-dependent transcription $(1,2,4,6,8,11,12)$. However, the number of cell types separated by centrifugal elutriation for cell cycle analyses described so far is limited, and a detailed investigation of the reproducibility of this method to analyze cell cycle parameters in different cell types is missing. We describe data that should help investigators to obtain reproducible results on cell cycle regulations in a wide variety of different cell types using the approach of centrifugal elutriation: $(i)$ analyzing a wide variety of mammalian cell types, we found that the quality of separation by centrifugal elutriation must reach a very specific level to enable one to properly study cell cycle regulations; (ii) we have optimized the centrifugal elutriation conditions to obtain highest quality of separation for 22 different primary cells and cell lines, focusing on those that are frequently used in investigations of cell cycle regulations; and (iii) our data allow general conclusions that could help optimize the conditions for elutriation of other cells.

We designed the elutriation system as described earlier $(3,5,7)$. In this system, the cells loaded into the elutriation chamber are subjected to the centrifugal force generated by the rotation of the rotor in an outward direction and to the fluid force pumped into the separation chamber (we routinely used the standard chamber) in an inward direction. In the elutriation chamber, a gradient of sedimentation velocity is established that decreases toward the center of rotation. During the loading process at constant rotation and pump speed, the cells are sedimented to a position in the separation chamber according to their sedimentation velocity (determined by size and density of the cell). The cells remain in the chamber as long as the two opposite forces are in equilibrium. This equilibrium is dependent on the average cell size, the loading pump and rotation speed and the time the cells have to reach the right sedimentation position. Homogeneous populations of cells with a specific size can be eluted out of the rotor by increasing the pump speed as well as by decreasing the rotation speed. During the course of our investigation, we found that increasing the pump speed led to much higher reproducibility of separation quality than decreasing the rotation speed. Accordingly, we routinely elutriated at constant rotation speed. We also used, for all elutriations described here, the Model JE-6B elutriator in a Model J2-21M centrifuge (Beckman Instruments, Fullerton, CA, USA). We used Masterflex ${ }^{\circledR}$ Model 6411-16 silicone tubing, and medium flow was controlled with a Masterflex pump with the standard Model 7016-20 pump head (Cole-Parmer, Vernon Hills, IL, USA). The elutriation medium was phosphate-buffered saline supplemented with $0.9 \mathrm{mM} \mathrm{CaCl}_{2}, 0.5 \mathrm{mM} \mathrm{MgCl}_{2}$ and $2 \%$ calf serum. Medium flow rate was increased in steps of $2-3 \mathrm{~mL} / \mathrm{min}$, and consecutive fractions were drawn. Each separated fraction was monitored by a flow cytometer (Beckton Dickinson, Vienna, Austria) after staining DNA. Adherent growing cells were trypsinized, and the enzyme reaction was stopped by concentrating all the cells in $45 \mathrm{~mL}$ of the medium described above containing $50 \%$ calf serum be- fore loading. Cells in suspension were concentrated by centrifugation $(150 \times$ g) $(2,3)$.

During the course of our investigation, we were confronted with three different levels of elutriation quality, which we termed categories A, B and C. In category A elutriations, the G1 fractions contained almost $100 \%$ G1 cells, the best S-phase fractions contained up to $80 \%$ S-phase cells, and the best $\mathrm{G} 2 / \mathrm{M}$ fractions contained also about $80 \%$ G2/M cells (Figure 1). The typical category B elutriation reflected the problem of enrichment of each cell cycle phase in the separated fractions, but all fractions maintained a relatively high amount of G1 cells. Accordingly, the early G1 fractions were pure, but the best S-phase fractions never contained more than 30\% S-phase cells, and the best $\mathrm{G} 2 / \mathrm{M}$ fractions were about $45 \%$ G2/M (Figure 1). In category C elutriations, we could separate pure G1 cells, but all the other fractions obtained reflected DNA distributions comparable to those of logarithmically growing cells (Figure 1). To get insights into the usefulness of the three categories of elutriations, we analyzed the different separated fractions for thymidine kinase (TK) activity, widely used as a marker for $\mathrm{S}$ phase-dependent regulation (9). Using the approach of centrifugal elutriation, TK activity has earlier been shown to be induced about 20-fold at the G1/S transition and to decrease during G2 in normal cells $(2,3,12)$. We detected this type of TK cell cycle regulation in category A elutriations (Figure 1 and Reference 3 ). In category B elutriations, the G1/S-specific up-regulation of TK was heavily diminished (about 35\%), and the downregulation during $\mathrm{G} 2$ was not gradual as seen in category A experiments. In category $\mathrm{C}$ elutriations, the cell cycle regulation of TK was almost totally abolished, with the highest induction of 2.5-fold (Figure 1). These data show that the quality of centrifugal elutriation must reach the separation efficiency of category A experiments to allow conclusions about the real and right cell cycle regulation of the analyzed parameter.

From these data, the question arose of which conditions one has to choose to reach this high quality of separation 
Table 1. Conditions for Centrifugal Elutriation of Different Cells

Pump Speed (mL/min)

Growtha Cell No. Load Time ${ }^{b}$ Loading Initial Final Temp. Speed Cat.c

\section{Primary Human Cells:}

Fetal fibroblasts

Adult fibroblasts

PHA ${ }^{\text {- }}$-stimulated lymphocytes

Primary Mouse Cells:

Fetal fibroblasts

Adult fibroblasts

Human Cell Lines:

293, adenovirus-transformed fibroblasts

HeLa, cervix carcinoma cells

EBVe-transformed lymphocytes

MOLT-4, acute lymphoblastic

leukemia

NB-4, acute promyelocytic leukemia S

$\mathrm{Y} 79$, retinoblastoma cells

S

A $\quad 1.8 \times 10^{8}$

A $\quad 1.2 \times 10^{8}$

S $2.8 \times 10^{8}$

$25 \mathrm{~min}$

$30 \mathrm{~min}$

$40 \mathrm{~min}$

\section{A $\quad 3.3 \times 10^{8} \quad 40 \mathrm{~min}$}

A $\quad 2.1 \times 10^{8} \quad 30 \mathrm{~min}$

A $\quad 1.5 \times 10^{8} \quad 35 \mathrm{~min}$

A $\quad 2.3 \times 10^{8}$

$35 \min$

$2.4 \times 10^{8}$

S $\quad 3.1 \times 10^{8}$

S $\quad 3.4 \times 10^{8}$

$30 \mathrm{~min}$

$40 \mathrm{~min}$

$30 \mathrm{~min}$

$2.9 \times 10^{8}$

$25 \mathrm{~min}$

Rat Cell Lines:

Rat1 fibroblasts

Rat1a fibroblasts

Rat1MycER, Myc over-expressing cells

Rat1p1093-E2F1, E2F-1

over-expressing

\section{Mouse Cell Lines:}

3T3 fibroblasts

3T6 fibroblasts

F9, embryonic carcinoma cells

SV-40f-transformed mouse

kidney cells

J558, myeloma cells

RAW309F.1.1, lymphoma cells

COP-8, polyoma-transformed fibroblasts

A

$$
\begin{aligned}
& 2.0 \times 10^{8} \\
& 3.1 \times 10^{8} \\
& 3.1 \times 10^{8}
\end{aligned}
$$$$
2.4 \times 10^{8}
$$$$
2.6 \times 10^{8}
$$

$$
\text { A }
$$$$
2.2 \times 10^{8}
$$

$30 \mathrm{~min}$

\section{$30 \mathrm{~min}$}

$30 \mathrm{~min}$

5 min

$30 \mathrm{~min}$

$25 \mathrm{~min}$

$30 \mathrm{~min}$

\section{A $\quad 2.5 \times 10^{8}$}

A $\quad 2.9 \times 10^{8}$

$30 \mathrm{~min}$

$30 \mathrm{~min}$

$$
2.0 \times 10^{8}
$$

$2.2 \times 10^{8}$

A $\quad 2.4 \times 10^{8}$

A $\quad 0.9 \times 10^{8}$

\section{$5 \mathrm{~min}$}

5 min

$25 \mathrm{~min}$

$30 \mathrm{~min}$

$\begin{array}{ll} & 1.8 \times 10^{8} \\ \text { A } & 1.4 \times 10^{8} \\ \text { A } & 1.6 \times 10^{8} \\ \text { A } & 2.3 \times 10^{8}\end{array}$

20 min

$30 \mathrm{~min}$

$30 \mathrm{~min}$

$30 \mathrm{~min}$

$$
\begin{array}{ll}
1.9 \times 10^{8} & 10 \mathrm{~min} \\
3.5 \times 10^{8} & 30 \mathrm{~min}
\end{array}
$$

aA = adherent; $\mathrm{S}=$ suspension

btime of constant loading pump speed to let the cells enter the system

${ }^{c}$ Cat. $=$ category of elutriation quality (Figure 1)

dphytohemagglutinin

eEpstein-Barr virus

fsimian virus 40

$\begin{array}{llllll}16 & 24 & 56 & 25^{\circ} \mathrm{C} & 520 \times g & \text { A } \\ 20 & 26.4 & 55.2 & 25^{\circ} \mathrm{C} & 580 \times g & \text { A } \\ 10.4 & 18.4 & 40 & 20^{\circ} \mathrm{C} & 580 \times g & \text { A }\end{array}$

$\begin{array}{llllll}24 & 32 & 66.4 & 25^{\circ} \mathrm{C} & 580 \times g & \mathrm{~B}\end{array}$

$\begin{array}{lllll}27.2 & 32 & 64 & 25^{\circ} \mathrm{C} & 580 \times g\end{array}$

$\begin{array}{lllll}20 & 24 & 52.8 \quad 25^{\circ} \mathrm{C} & 580 \times g & \mathrm{~A}\end{array}$

$\begin{array}{lllll}34.4 & 40 & 61.6 & 25^{\circ} \mathrm{C} & 580 \times g\end{array}$

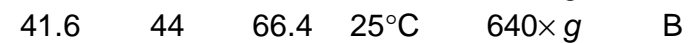

$\begin{array}{lllll}14.4 & 20 & 40 & 25^{\circ} \mathrm{C} & 580 \times g\end{array}$

$\begin{array}{llllll}12 & 16 & 34.4 & 25^{\circ} \mathrm{C} & 580 \times g & \mathrm{~A}\end{array}$

$\begin{array}{lllll}11.2 & 17.6 & 33.6 & 25^{\circ} \mathrm{C} & 580 \times g\end{array}$

$\begin{array}{lllll}12.8 & 20 & 39.2 & 25^{\circ} \mathrm{C} & 580 \times g\end{array}$

$\begin{array}{llllll}26.4 & 31.2 & 63.2 & 20^{\circ} \mathrm{C} & 580 \times g & \text { A } \\ 26.4 & 31.2 & 63.2 & 25^{\circ} \mathrm{C} & 580 \times g & \text { B } \\ 26.4 & 31.2 & 63.2 & 25^{\circ} \mathrm{C} & 580 \times g & \mathrm{C} \\ 28 & 32 & 66.4 & 25^{\circ} \mathrm{C} & 580 \times g & \text { A } \\ 26.4 & 31.2 & 63.2 & 25^{\circ} \mathrm{C} & 580 \times g & \text { A }\end{array}$

$\begin{array}{lllll}28 & 32 & 66.4 & 25^{\circ} \mathrm{C} & 580 \times g\end{array}$

$\begin{array}{llllll}20 & 26.4 & 66.4 & 22^{\circ} \mathrm{C} & 580 \times g & \text { A } \\ 14.4 & 20 & 64 & 25^{\circ} \mathrm{C} & 580 \times g & \text { A } \\ 17.6 & 25.6 & 60.8 & 25^{\circ} \mathrm{C} & 580 \times g & \mathrm{~B} \\ 36.8 & 42.4 & 98.4 & 25^{\circ} \mathrm{C} & 1320 \times g & \mathrm{C} \\ 20 & 26.4 & 60.8 & 25^{\circ} \mathrm{C} & 580 \times g & \mathrm{~A} \\ 17.6 & 25.6 & 49.6 & 25^{\circ} \mathrm{C} & 580 \times g & \mathrm{~A} \\ & & & & & \\ 20 & 22.4 & 48 & 25^{\circ} \mathrm{C} & 580 \times g & \mathrm{~B} \\ 20.8 & 28.8 & 52.8 & 25^{\circ} \mathrm{C} & 580 \times g & \mathrm{~A} \\ 17.6 & 20 & 50.4 & 25^{\circ} \mathrm{C} & 580 \times g & \mathrm{~A} \\ 20 & 28.8 & 80 & 25^{\circ} \mathrm{C} & 580 \times g & \mathrm{~A} \\ & & & & & \\ 24 & 34.4 & 74.4 & 25^{\circ} \mathrm{C} & 580 \times g & \mathrm{~B} \\ 22.4 & 24 & 72 & 18^{\circ} \mathrm{C} & 580 \times g & \mathrm{C}\end{array}$


by centrifugal elutriation in different cell types. Our investigation revealed that in using the elutriation system described above, the most important step of the whole procedure was to reach a perfect equilibrium during loading of the cells; we have optimized the elutriation conditions for $2 \times 10^{8}$ Rat 1 cells concerning loading time and loading pump speed. When we used the same conditions for loading of $3.1 \times 10^{8}$ Rat 1 cells, the elutriation quality dropped from category A to B. When we also shortened the loading time from 30 to 5 min, the obtained elutriation quality was category $\mathrm{C}$ (Figure 1 and Table 1 ). In Table 1, we present the optimized elutriation conditions for 22 different cell types that are widely used in investigations of cell cycle regulations (cul-

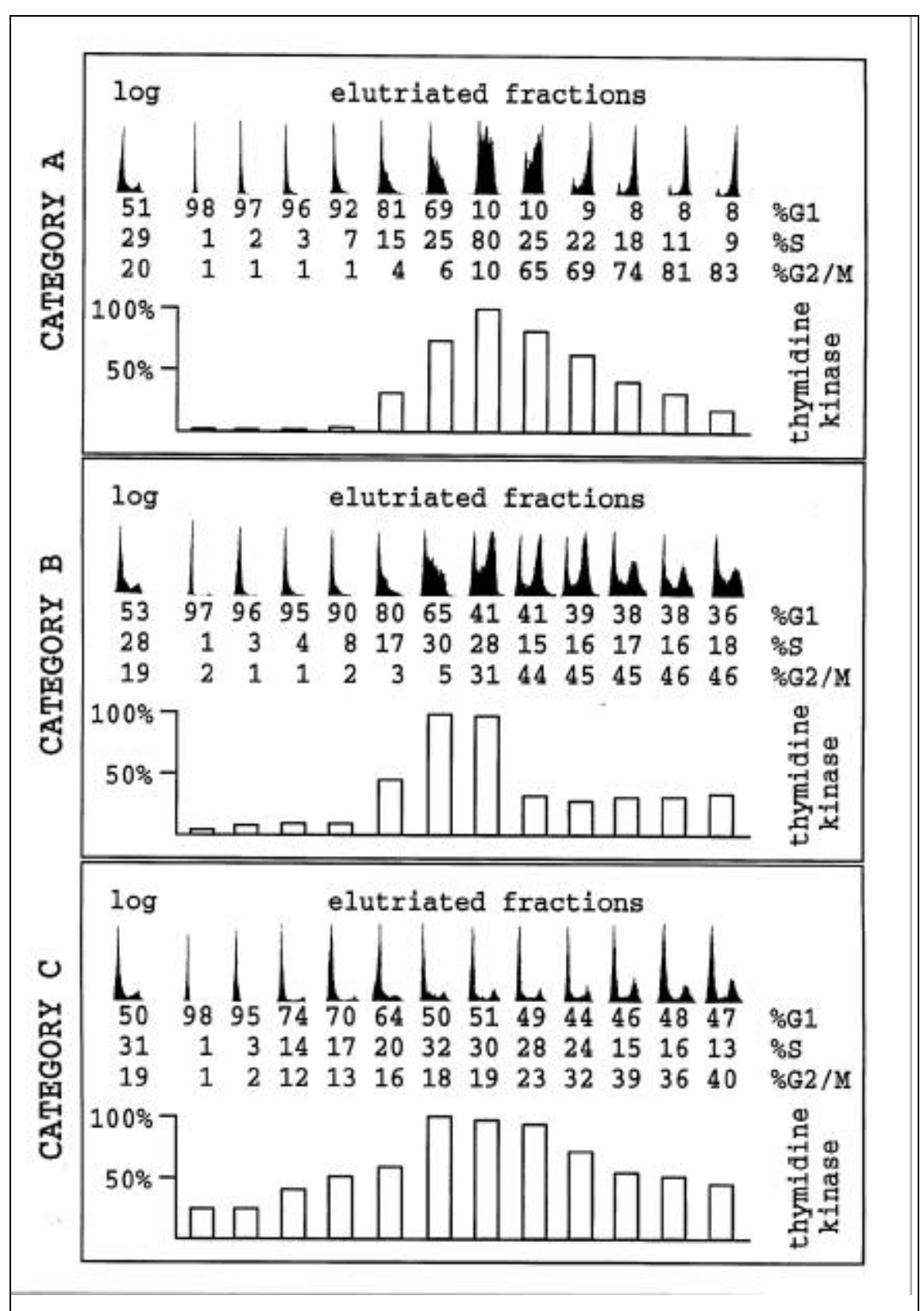

Figure 1. Categories of elutriation quality. Logarithmically growing Rat 1 cells were separated according to their different cell cycle phases by centrifugal elutriation using three different experimental conditions (the conditions are described in detail in Table 1). The cell fractions obtained were cytofluorometrically analyzed for DNA distribution (upper panels) and TK activity (given relative to the highest value set to $100 \%$ ). tivation of primary cells is described in Reference 3). For some cells, we present conditions that led to lower separation qualities to help investigators to avoid possible problems. Our results also allow investigators to draw some more general conclusions that could help them to optimize the conditions of centrifugal elutriation for other cell types of interest: ( $i$ ) increasing the pump speed led to more reproducible separation data on the analyzed cell types than decreasing the rotor speed; (ii) the quality of separation in Model JE-6B elutriators is heavily dependent on the number of loaded cells. As more cells are loaded, the time of equilibration should become longer; (iii) we were never able to elutriate more than 3 $\times 10^{8}$ adherent cells in category A, not even after very long equilibration time (up to $2 \mathrm{~h}$ ), using the standard elutriation chamber; (iv) suspension cells are usually smaller and must accordingly be equilibrated at lower pump speeds. Nonadherent cells can be separated at high quality even when more than $3 \times$ $10^{8}$ cells are loaded; and $(v)$ the temperature in the elutriation system (in the range of $15^{\circ}-30^{\circ} \mathrm{C}$ ) does not affect the separation quality. Elutriation at higher or lower temperature should affect the fraction at which the cells exit, since both the density and viscosity of the medium affect the sedimentation velocity and change as a function of temperature (particularly viscosity).

In conclusion, we want to stress that centrifugal elutriation used with optimized conditions for the cell type of interest leads to highly reproducible and artifact-free data on cell cycle regulations in all different cell types used so far. However, centrifugal elutriation in categories B and C does not allow conclusions about the cell cycle regulation of the analyzed parameter.

\section{REFERENCES}

1.Dulic, V., E. Lees and S.I. Reed. 1992. Association of human cyclin $\mathrm{E}$ with a periodic G1S phase protein kinase. Science 257:19581961.

2.Hengstschläger, M., E. Hengstschläger-Ottnad, O. Pusch and E. Wawra. 1996. The role of p16 in the E2F-dependent thymidine kinase regulation. Oncogene 12:1635-1643.

3.Hengstschläger, M., M. Knöfler, E.W. Müllner, E. Ogris, E. Wintersberger and E. 
Wawra. 1994. Different regulation of thymidine kinase during the cell cycle of normal versus DNA tumor virus-transformed cells. J. Biol. Chem. 269:13836-13842.

4.Hengstschläger, M., I. Mudrak, E. Wintersberger and E. Wawra. 1994. A common regulation of genes encoding enzymes of the deoxynucleotide metabolism is lost after neoplastic transformation. Cell Growth Differ. 5:1389-1394.

5.Kauffman, M.G., S.J. Noga, T.J. Kelly and A.D. Donnenberg. 1990. Isolation of cell cycle fractions by counterflow centrifugal elutriation. Anal. Biochem. 191:41-46.

6.Koff, A., A. Giordano, D. Desai, K. Yamashita, J.W. Harper, S. Elledge, T. Nishimoto, D. Morgan, B.R. Franza and J.M. Roberts. 1992. The formation and activation of a cyclin E-Cdk2 complex during the G1 phase of the cell cycle. Science 257:16891694.

7.Marraccino, R.L. and P.C. Keng. 1995. Centrifugal elutriation, p. 53-62. In M. Pagano (Ed.), Cell Cycle-Materials and Methods. Springer-Verlag, Berlin.

8.Pagano, M., R. Pepperkok, F. Verde, W. Ansorge and G. Draetta. 1992. Cyclin A is required at two points in the human cell cycle. EMBO J. 11:961-971.

9.Pardee, A.B. 1989. Events and regulation of cell proliferation. Science 246:603-608.

10.Pardee, A.B. and K. Keyomarsi. 1992. Modification of cell proliferation with inhibitors. Curr. Opin. Cell Biol. 4:186-191.

11.Pusch, O., T. Soucek, E. Wawra, E. Hengstschläger-Ottnad, G. Bernaschek and M. Hengstschläger. 1996. Specific transformation abolishes cyclin D1 fluctuation throughout the cell cycle. FEBS Lett. 385:143-148.

12.Sherley, J.L. and T.J. Kelly. 1988. Regulation of thymidine kinase during the cell cycle. J. Biol. Chem. 263:8350-8358.

Work in M.H.'s laboratory is supported by the Komission Onkologie, the Austrian Nationalbank and the Hans and Blanca Moser Stiftung from the Medical Faculty of the University of Vienna. Address correspondence to Markus Hengstschläger, University of Vienna, Obstetrics and Gynecology, Department of Prenatal Diagnosis and Therapy, Währinger Gürtel 18-20, A1090 Vienna, Austria. Internet: markus. hengstschlaeger@akh-wien.ac.at

Received 12 November 1996; accepted 27 February 1997.

\section{Hengstschläger, O. Pusch, T. Soucek, E. Hengstschläger- Ottnad and G. Bernaschek University of Vienna \\ Vienna, Austria}

\section{Nonselective $U R A 3$ Colony-Color Assay in Yeast ade1 or ade2 Mutants}

BioTechniques 23:237-242 (August 1997)

Phenotypes of the yeast Saccharomyces cerevisiae are normally assayed with synthetic, minimal media lacking one or more amino acids (5). For some markers, such as those in the adenine biosynthetic pathway, phenotypes can be distinguished by colony color on nonselective (rich) media. Thus, ade 1 and ade 2 mutants produce red or pink colonies, while wild-type yeast colonies are white. Color markers have advantages over typical selectable markers. Color markers can be assayed in a single step, whereas typical markers are usually assayed by replica plating to media lacking a particular metabolite. Although single-step selection is possible for most markers, selective strategies may prevent certain products from being detected, and this may compromise experimental analyses. Thus, screening color phenotypes on nonselective media facilitates more complete product analysis for some types of experiments, such as those in which mixed (sectored) colonies may arise.

$U R A 3$ is a very popular gene for studies in yeast because media are available that allow selection for and against both ura3 mutants and wildtype $U R A 3$ strains $(1,5)$. This positivenegative selection system is often used to effect "in-out" gene replacement (4). We use URA3 in our assays of doublestrand break (DSB)-induced mitotic recombination. We recently performed a study involving assays for sectored $\mathrm{Ura}^{ \pm}$colonies that were expected to arise through segregation of a palindromic loop mismatch in an intrachromosomal recombination intermediate. Recombination was induced in liquid cultures by DSBs created in vivo in an HO nuclease site (3) located 21 bp upstream of the palindrome in strain YW14-409, which carries a non-tandem duplication of $u r a 3$ (and is MATainc, ade2-101, his3-200, trp1- $\Delta 1$; unpublished). After DSB induction, cells 